\title{
The Stands of the Political Parties in the Republic of Macedonia towards the 2001 Armed Conflict and the Signing of the OFA Agreement
}

\author{
Prof. Dr. Etem Aziri \\ Faculty of Public Administration and Political Science, \\ South East European University, Tetovo, Republic of Macedonia \\ Email: e.aziri@seeu.edu.mk \\ Bilall Lutfiu, MSc \\ Faculty of Public Administration and Political Science, \\ South East European University, Tetovo, Republic of Macedonia \\ Email: lutfiub@hotmail.com
}

Doi:10.5901/ajis.2014.v3n3p388

\begin{abstract}
Although the dissolution of the ex Yugoslav Federation is one of the bloodiest processes of the newer European history, due to e specific set of factors and circumstances the Republic of Macedonia was the only country that managed to separate from the federation without a single shot being fired. But as it was later proved, The Republic of Macedonia was not immune and was faced with an armed conflict at the beginning of this century due to the many unsolved issues that had mostly to do with the unsettled interethnic relations in the country. The Armed Conflict of 2001, was without a doubt perceived a turning point in the development of the Republic of Macedonia. This paper strives to provide insides regarding the attitudes of the main political parties and political elites in the country regarding the 2001 conflict and the evolution in their attitudes during the conflict and nowadays a whole century after the conflict has ended.
\end{abstract}

Keywords: Armed Conflict of 2001, Ohrid Framework Agreement

\section{Introduction}

Although an ex-Yugoslav Republic, Macedonia has undergone a very specific historical development, starting with the process of gaining its independence up to now. The Republic of Macedonia was the only republic that managed to gain its independence without any bloodshed during the breakout of the Ex Yugoslav Federation. On the other side it has remained the only Republic that although being accepted as independent, still has major unsolved issues with all its neighboring countries with the exception of the Republic of Albania and the Republic of Kosovo. Macedonia managed to mark its border with Serbia a decade after it gained its independence while the Serb Orthodox Church continues to refuse accepting the Macedonian Orthodox Church as an independent one. Neighboring Greece and Macedonia has many unsolved issues, mainly having to do with the name of the country and perhaps even the identity of the ethnical Macedonians. On the other hand, Macedonia has unsolved issues with neighboring Bulgaria when it comes to several important historical figures and events as well as the Macedonian language.

Although the Republic of Albania and the Republic of Kosovo, being two neighboring countries with an overwhelming majority of ethnic Albanian population have accepted the Republic of Macedonia as a sovereign country in its entirety, yet many issues have remained unsolved among the ethnic Macedonians and the ethnic Albanians that form two of the numerically largest ethnicities in the country.

During its discourse of development as an independent country, the Republic of Macedonia has been faced with several main challenges both internally and externally. It has undergone a rather difficult process of transition, followed by major social challenges. The process of privatization has in many cases been considered as bad, criminalist, unfair etc. Although for a period of time, Macedonia was considered to be one of the most advanced countries in the Balkans in terms of fulfilling the preconditions for Euro-Atlantic integrations, it has undergone a process of sufficient drawback due to both internal and external pressures and weaknesses.

Surely one of the main issues that has been in many cases a burden to the overall development of the Republic of Macedonia have been the unsolved inter-ethnic relations, mainly due to a major gap in understanding the nature of the country among the two main ethnical groups. The ethnic Macedonians tend to view Macedonia as a crooning of centuries in sacrifice for the creation of an ethnic Macedonian country and therefore prefer to consider the Republic of Macedonia 
as a country of the Macedonians in which other ethnicities live and co-exist as well. On the other hand in many cases the ethnic Albanians tend to view the Republic of Macedonia as Tito's creation and consider themselves autochthon to the regions they inhabit for the moment. Besides this, the Macedonian political elites in many cases have stood shoulder to shoulder with the Serb political elites in the creation of state policies which in many cases were anti-Albanian and this has without a doubt complicated the inter-ethnic relations even further.

Besides this even the ethnical structure of the population in the Republic of Macedonia is not clear enough due to the fact that the last census was conducted a decade ago. Many announced Macedonian politicians and experts have in continuity been warning the ethnic Macedonian population that due to the gap in the level of birth-rate the number of ethnic Albanians has been growing and due to this their participation in the general population has increased. The failed census some time ago, complicates this issue even further. Besides this the scientific Albanian community has expressed serious doubts in the correctness of all censuses previously conducted in the Republic of Macedonia

Although the Republic of Macedonia has been from the very beginning declared to be a secular country in which all religious groups are equal in front of the law, one cannot shake the feeling that after all the Macedonian Orthodox Church has in continuity been privileged compared to the other Religious organizations. Religion is another issue that has until now not been addresses by the public opinion in the Republic of Macedonia specially having in mind that the religious structure is not compliant with the ethnical structure. This is due to the fact that a vast majority of the population that have been declared as ethnical Albanians are Muslim and this is the case with the ethnical turks as well. According to the 2002 census these two ethnical groups comprise around $29 \%$ of the population. On the other hand a part of the 53879 Roma populations are Muslim as well as a part of the 1297981 Macedonian populations.

Another issue that should be mentioned is that during the first decade of its functioning as an independent country, the Republic of Macedonia functioned in "steer waters". The Albanian population took part in all political processes in terms of being part of the electoral process and had its representatives in the Parliament and the Government. But, on the other hand these two organs, in many cases were "ignorant" to the demands of the Albanians for equality.

Perhaps the refusal of the Macedonian political elites, to fulfill and show respects for the basic human and citizen's right of the Albanians was the main reason why the country underwent from s stage in which the first president Gligorov called it an "oasis of peace" to a process of an interethnic conflict.

The Albanian demands, were ranging from the wish to use their national Flag and the oficialization of the Albanian language up to very practical and reasonable demands such as the right to have an University in which the Albanian youth would learn in its mother tongue and the right to equal treatment in employment.

The refusal of the rightful demands of the ethnical Albanian population was followed by many cases of state violence against the Albanian population by the Macedonian police force. Some of the main cases that will be remembered are the Ladorishta events in which the police undertook a violent campaign against ethical Albanians in the Struga region, the case with the Tetovo University in which a protester was shot in cold blood and no-one took the blame up to the Gostivar case in which three people lost their lives. Two of them were shot in cold-blood while the third died due to the many injuries inflicted by the special police. Hundreds of citizens were brutally beaten up. In the Bit Pazar case tanks were used against the unarmed Albanian protesters. These cases are only a small portion of the many cases in which the judiciary never undertook any measures.

Due to the above mentioned activities and the feeling that the Macedonian state will never allow the Albanians to realize their rights in a peaceful manner, ethnical Albanians gathered in the National Liberation Army and thus started the armed conflict of 2001.

\section{The Stands of the Political Parties Toward the Armed Conflict of 2001 and the Signing of the Ohrid Framework Agreement}

The fighting between armed Albanians and Macedonian security forces in 2001 ended in August of that year with the signing of the Framework Agreement at Ohrid. Since then, many of Macedonia's political leaders have vowed to develop cooperation between the two ethnic communities, which have long been separated not only by language and religion but also socially, economically, and politically. One of the key challenges facing the country is to extend this determination to promote cooperation from the political to the social level. (Beska\&Najceska, 2004,2).

Although OFA has become one of the main terms used by the politicians in Macedonia, the fact remains that the political elites and political party's views and attitudes toward the conflict that resulted with the signing of OFA and the OFA itself differ and in some cases have changed during this period.

Without a doubt the opinions specially differ between representatives of the Albanian and the Macedonian community but also among representatives of these communities. Besides this it should be mentioned that the attitudes 
and stands have changed during the very period of the seven months that the conflict lasted for.

\subsection{The stands of the political parties of the Albanians toward the armed conflict of 2001 and the signing of the Ohrid Framework Agreement}

During the 2001 armed conflict as well as for the most of the period since the independence of the Republic of Macedonia, the Albanian political campus was dominated by two main political parties:

- The Party for Democratic Prosperity (PDP). A political party that had been member of the Government of the republic of Macedonia from the independence of the country up to the 1998 elections thus had been member of the Government during the period in which all of the anti-Albanian actions were undertaken.

- The Democratic Party of the Albanians (DPA). A former wing of the PDP that has separated from the party years ago and was member of the Government since the beginning of 1999.

Their attitudes regarding the armed conflict of 2001 evolved largely as the conflict developed. Perhaps one of the most noted declarations of the PDP regarding the conflict was the one given by the spokesperson of this party after th first attack of the NLA members on the police station in the village of Tearce. In this declaration the NLA members that performed the attack were addressed as "terrorists" by the spokesperson of the largest Albanian opposition party of the time.

On the other had at his time, the representatives of the DPA although worried saw the attack mostly as a single event and not as a prelude to an armed conflict. In fact the President of the DPA at that time declared that "I believe that Macedonia is after all a stable country because the main political actors both from with the country and outside it are interested in maintaining its stability. A small group of people can create great tensions if there is a lack of political reaction. An action, such as the one in tearce requires no more than three to four people. I believe that such actions cannot present a threat for a serious and democratic country such as Macedonia strives to be". ( Makedonija Denes, 31.January,2001).

After the armed conflict in the village of Tanushevci the vice-president of DPA at that time, expressing the opinion that the conflict is not in the best interest of the Albanians would declare "I know that the attacks are not beneficiary for the advancement of the status of the Albanians in the Republic of Macedonia. Therefore DPA is against the violence and considers that the Albanians can solve their problems only through political means". (Fakti, 28.February.2001)

On the other hand, the Coordinator of the Parliamentary Group of PDP expressing his concerns regarding the security situation blamed the government's policies for what was happening. (Fakti, 28.February.2001

On the 8.March.2001 in a visit to the President of the Republic of Macedonia while heading a delegation of PDP, its president would declare that his party os strongly commited to the defense of the territorial integrity of the country and condemn the attack in Tanushevci as well as expressed their willingness to gat politically more engaged in field work. (Flaka, 10.March.2001)

After the declaration of the political demands by the NLA the vice-presidents of both Albanian parties declared that in fact what is required $b$ the NLA is already a part of each of the parties' political programs (Fakti, 12.March.2001). These claims were also made by the National Democratic Party through its secretary general (Fakti, 13.March.2001).

As the conflict was threatening to become even more serious both Albanian parties came out with demands that the conflict should be stopped before it escalates in a real civil war. After several meetings with the representatives of the international community the president of DPA on behalf of all Albanian political leaders declared that the conflict originates from within Macedonia and required that the conflict should be addresses and resolved in a peaceful manner. This was the first time that officially an Albanian political party condemned the armed forces of Macedonia for the usage of too much firepower without having a need to do so. ( Fakti. 21.March.2001)

Therefore the 20.March.2001 can be considered one of the main political turning points during the conflict. Even besides the good will, the conflict continued with an increased intensity and this on the other had resulted in an even broader political support for the NLA on the side of the Albanian political parties. For the first time the political representatives of the Albanians required from the representatives of the international community that the Euro-Atlantic integration processes should be frozen and the country should transform itself into a really functional multi-ethnic country.

On the 13.May.2001 a Government of Large Coalition including all major political parties was created. A few days later on 24.May.2001 the Prizren Accords were signed by the presidents of DPA and PDP, Arben Xhaferi and Imer Imeri as well as the political representative of NLA Ali Ahmeti. This was followed by a large scale military action against the Albanian villages specially in the Kumanovo region. It should be noted that all political representatives of the Albanians as well as many Macedonian political representatives refused the proposals of the PM for the declaration of a State of War.

An anslysis of the declarations made by the official representatives of the Albanian political parties in the period 
from the Prizren Agreement until the signing of the OFA, shows that as time passed there was a tendency of even further and stronger political support for the NLA, specially having in mind the activities undertaken by the Macedonia police and armed forces.

Although OFA was signed by the presidents of the two major Albanian political parties, the fact remains that even in the period of its signature there was an impression that the agreement was being signed under international pressure and in order to avoid further escalation of the conflict. Perhaps this is the main reason why the Albanian political representatives have had in continuity disagreements regarding the way how OFA is to perceived as well as the path towards its implementation. Besides this there were major differences in perceiving the implementation of OFA among the Albanian and Macedonian political elite.

While the Albanian MP's, aware of the practical importance of incorporating the main principles of OFA in the Constitution insisted on quick and precise implementation of the accords, individual Macedonian politicians has different views. In several cases an intervention by the international mediators was required in order to unblock the processes.

Even besides the obvious problems, the fact remains that ever since the Agreement was signed the political parties of the Albanians including PDP, DPA and the newly formed Democratic Union for Integration (DUI) as a political representation of the ex NLA were firmly determined to implement the accords in all fields although many debated have been conducted when it comes to the intensity and quality of implementation of the accords.

In the spirit of the Ohrid Framework Agreement a large number of Albanians have been employed in the state administration and partly in the public enterprises, a law for the usage of the languages of the ethnicities that comprise $20 \%$ of the general population has been adopted in the Parliament as well as a law for the usage of the Albanian flag. Regardless the changes made, the expert community and the opposition have quite often argued that although a large number of Albanians have been employed, still most of them remain undistributed across institutions and therefore unproductive.

Besides this the usage of the Albanian language has been limited only to the municipalities in which at least $20 \%$ of the population are ethnic Albanians as well as to certain usages in the central government institutions but only in the cases when those institutions are managed by ethnic Albanians and not according to law. Even in the Parliament, the usage of Albanian language is limited only to plenary sessions. Regarding the usage of the Albanian flag many debates have been made. Although the Albanian flag can be used, it can be used only in certain cases and only smaller in size compared to the official flag of the country.

\subsection{The stands of the political parties of the Macedonians toward the armed conflict of 2001 and the signing of the Ohrid Framework Agreement}

During the 2001 armed conflict as well as for the most of the period since the independence of the Republic of Macedonia, the Albanian political campus was dominated by two main political parties:

- Internal Macedonian Revolutionary Organization -Democratic Party for Macedonian National Unity (IMRODPMNU). A political party that had been in Government for the most of the period since the 1998 elections.

- Social Democratic Union of Macedonia (SDUM). A political party that has been in Government for the most part of the first decade of the country's independence.

When it comes to the attitudes of the Macedonian political parties and elites toward the armed conflict of 2001 and the Ohrid Framework Agreement not many differences exist regardless weather they were in position or opposition.

Put in simple words all political parties of the Macedonians had a nugatory attitude toward the conflict and the NLA. Another common treat shared by all of them is the refusal to accept the fact that the NLA and the conflict originate from within Macedonia. Perhaps in order to preserve their "idyllic view" of Macedonia as a democratic country the Macedonian political parties and elites, preferred to consider the conflict as being imported from outside mainly from the neighboring Republic of Kosovo.

During the whole period of the lasting of the conflict the Macedonian political elites, refused to publicly accept the fact that a portion of their own citizens faced with their lack of willingness to guarantee their basic group and ethnical right took up arms as a solution to solving their problems.

The Macedonian political parties, although not with an equal intensity, were all in favor of an armed solution to the conflict hoping that with a swift military response they would be able to resolve the situation. On the other side the practice was different.

The armed forces proved incapable to perform a swift victory against the NLA forces and as each day passed the NLA gained even stronger support among the Albanian population. In return the Government responded with providing weapons to the Macedonian civilians which on the other hand was a sign that the conflict can easily escalate into a full 
scale civilian war that could perhaps even grow into a new Balkan war.

Faced with such possible scenarios for the future of the country the Macedonian political elite slowly became aware that perhaps the best solution would be of a political nature, an agreement that would ensure equality among all citizens while ensuring the territorial integrity of the country. After all even the NLA itself never required territorial solutions but rather improved rights for the ethnic Albanian population.

Perhaps the above mentioned reasons were of crucial importance for the acceptance of the Ohrid Framework agreement by the major Macedonian political parties and the signing of OFA by their presidents.

\section{Conclusions and Recommendations}

The determination of the reasons and consequences of the armed conflict of 2001 is of great importance for the future of the Republic of Macedonia. Even now, more than a decade since the end of the conflict, a decade in which the ex managerial structures of the NLA organized within the Democratic Union for Integration have been a part of the government, there are "two truths" regarding the armed conflict.

The Macedonian political elites continue to consider the conflict as imported from Kosovo and in certain cases have gone so forth in such accusations as to even acuse th international community of stimulating the armed conflict. On the other hand the Albanian side addresses the conflict as an internal one and resulting from the unsolved ethnical issues.

Regardless, it is of great importance to determine the reasons behind the conflict in order to provide for a real democratization of the country, specially having in mind that the conflict itself ended without having a victor and in a phase that allowing for both sides to feel as being victorious. Besides this, both the Albanian and Macedonian side should learn to live the past aside and focus on the future that they will need to build with joint efforts.

\section{References}

Beska V.P and Najceska M. (2004). Macedonia: Understanding History, Preventing Future Conflict. Pp. 2.

Makedonija Denes, 31.January,2001

Fakti, 28.February.2001

Flaka, 10.March.2001

Fakti, 13.March.2001 